\title{
RESISTANCE OF POTATO GENOTYPES TO Meloidogyne javanica ${ }^{1}$
}

\author{
JAQUELINE TAVARES SCHAFER ${ }^{2 *}$, CESAR BAUER GOMES ${ }^{3}$, ARIONE DA SILVA PEREIRA $^{3}$, FERNANDA \\ FERREIRA CRUZ ${ }^{2}$, DANIELLE RIBEIRO DE BARROS ${ }^{2}$
}

\begin{abstract}
The objective of this study was to evaluate the resistance of a group of clones and cultivars from the potato breeding program of Embrapa to Meloidogyne javanica. The experiment was conducted at Embrapa Temperate Climate, Pelotas / RS, under greenhouse conditions at temperatures of $25 \pm 5^{\circ} \mathrm{C}$. Individual potato plants of different genotypes [BRSIPR Bel, BRS F63 (Camila), CL02-05, F23-11-06, F32-02 -06, F38-03-07, F189-09-06, F23-24-06 and F22-01-08], kept in pots with sterilized soil were inoculated with 5,000 eggs and $\mathrm{J} 2$ of $M$. javanica, using six replicates per treatment. The susceptible control, potato cultivar BRS Ana was inoculated with the same level of inoculum. Fifty-five days after inoculation, the number of galls on the roots of each plant was determined as well as the number of protuberances caused by nematodes in the different treatments. Then, the roots of each plant were processed for counting the number of eggs and J2, as well as determining the nematode reproduction factor (FR: final population / initial population). All genotypes were susceptible (FR> 1.00) to $M$. javanica. However, there were different levels of susceptibility among the cultivars tested.
\end{abstract}

Keywords: Root-knot nematode. Susceptibility. Solanum tuberosum.

\section{REAÇÃO DE GENÓTIPOS DE BATATA A Meloidogyne javanica}

\begin{abstract}
RESUMO - Objetivou-se com esse trabalho, avaliar a reação de um conjunto de clones e cultivares de batata do programa de melhoramento genético da Embrapa a Meloidogyne javanica. O experimento foi desenvolvido na Embrapa Clima Temperado, Pelotas/RS, em casa-de-vegetação sob temperaturas de $25 \pm 5^{\circ} \mathrm{C}$. Plantas individuais de batata dos diferentes genótipos [BRSIPR Bel, BRS F63 (Camila), CL02-05, F23-11-06, F32-0206, F38-03-07, F189-09-06, F23-24-06 e F22-01-08], mantidas em vasos com solo esterilizado, foram inoculadas com 5.000 ovos $+\mathrm{J} 2$ de $M$. javanica, utilizando-se seis repetições por tratamento. Como testemunha suscetível, plantas de batata da cultivar BRS Ana foram inoculadas com o mesmo nível de inóculo. Decorridos 55 dias da inoculação, avaliou-se o número de galhas nas raízes de cada planta e determinou-se o número protuberâncias (pipocas) causadas pelo nematoide/tubérculo nos diferentes tratamentos. Em seguida, as raízes de cada planta foram processadas para contagem do número de ovos $+\mathrm{J} 2$ e determinação do fator de reprodução do nematoide (FR: população final/população inicial). Todos os genótipos comportaram-se como suscetíveis $(\mathrm{FR}>1,00)$ à $M$. javanica. No entanto, verificaram-se diferentes níveis de suscetibilidade entre os materiais avaliados.
\end{abstract}

Palavras-chave: Nematoide-das-galhas. Suscetibilidade. Solanum tuberosum.

\footnotetext{
*Corresponding author

${ }^{1}$ Received for publication in $04 / 28 / 2016$; accepted in $09 / 08 / 2016$

Paper extracted from the doctoral thesis of the first author.

${ }^{2}$ Department of Phytosanitary, Universidade Federal de Pelotas, Capão do Leão, RS, Brazil; jaquelinets@gmail.com, fernanda.ferreiracruz@gmail.com,danrbarros@hotmail.com.

${ }^{3}$ Laboratory of Phytopathology, Embrapa Clima Temperado, Pelotas, RS, Brazil; cesar.gomes@embrapa.br, arione.pereira@embrapa.br.
} 


\section{INTRODUCTION}

Potato culture (Solanum tuberosum L.) is affected by various phytosanitary problems which cause losses in production or influence the quality of tubers (ZAMBOLIM, 2011). Among these, nematodes pose serious problems to the crop in most growing regions (ESTEVES; MALEITA; ABRATES, 2015), the main cause of potato damage are root-knot nematodes (Meloidogyne spp.), lesions (Pratylenchus spp.) and cyst-forming (Globodera spp.) (YOUSSEF, 2013).

In Brazil, different species of the Meloidogyne genus are widely distributed in the various potato producing regions. Meloidogyne javanica (Treub) Chitwood and M. incognita (Kofoid \& White) are the most common species in culture (CHARCHAR, 1997; SILVA, 2009), and the most common in southern Brazil (SILVA, 2009; LIMA-MEDINA, 2013) and worldwide (VOVLAS et al., 2005).

Losses caused by root-knot nematode can reach $100 \%$ in potato producing areas. Also, variable losses occur as a result of the planting season and the level of soil infestation (GOMES; SOUZA, 2003). The external symptoms of tuber infection become visible in the form of protuberances (galls) of different sizes, commonly known as "popping" (GOMES; SOUZA, 2003). In a single potato crop with low initial population levels, the nematodes undergo at least three cycles, during which the invasion of tubers by newly hatched juveniles is continuous and can cause severe damage (BROWN et al., 2006).

Among the control measures employed, the use of nematicides is one of the most common in the management of root-knot nematodes in potato (PINHEIRO; SILVA; PEREIRA, 2015), especially in large areas. The use of resistant cultivars is one of the most used management practices as a result of its low cost and efficiency. However, among the potato cultivars planted in Brazil, most are of European origin and those developed in different climatic conditions, do not exhibit resistance to $M$. javanica. Thus, the use of resistant or less susceptible cultivars is an important practice in the management of rootknot nematode, and reduces the use of chemicals in areas infested by these pathogens (GRECO, 1993).

Considering the limitations above mentioned, the objective of this study was to evaluate the resistance of different potato cultivars and clones to $M$. javanica and estimate the nematode damage to the tubers, under greenhouse conditions.

\section{MATERIAL AND METHODS}

Two cultivars [BRSIPR Bel and BRS F63 (Camila)] seven potato clones (CL02-05, F23-11-06,
F32-02-06, F38-03-07, F189-09-06, F22-01- 08 and F23-24-06) from the breeding program of Embrapa, were evaluated for genetic resistance and damage caused by $M$. javanica under greenhouse conditions $\left(25 \pm 5^{\circ} \mathrm{C}\right)$, at Embrapa Temperate Climate, PelotasRS.

As the nematode inoculum, we used an agressive population of $M$. javanica (Est J3) from potato (LIMA-Medina, 2013), which was grown and maintained on tomato (Solanum lycopersicum Mill.) $\mathrm{Cv}$. "Rutgers" in a greenhouse $\left(25 \pm 5^{\circ} \mathrm{C}\right)$.

Individual plants of different genotypes, kept in pots with $4.5 \mathrm{~kg}$ of soil sterilized in an autoclave, were inoculated with an aqueous suspension containing 5,000 eggs + second stage juveniles (J2) of M. javanica (HUSSEY; BARKER, 1973 modified by Boneti; FERRAZ, 1981). As a control, potato plants of the susceptible cultivar BRS Ana (LIMAMEDINA, 2013) were inoculated with the same level of pathogen inoculum. The experiment was conducted in a completely randomized design with six replications.

Fifty-five days after inoculation, the roots of each plant were separated from the shoot and the number of galls were evaluated. Subsequently, the extraction of eggs $+\mathrm{J} 2$ nematode from the roots of each plant (final population) was carried out (HUSSEY; BARKER, 1973 modified by Boneti; FERRAZ, 1981) to quantify and determine the reproduction factor $(\mathrm{FR}=$ final population $/$ initial population) of $M$. javanica (OOSTENBRINK, 1966) in each repetition. Tubers were also evaluated for the number of protuberances present in a predetermined area $1,76 \mathrm{~cm}^{2} /$ tuber, using three tubers for each repetition (LIMA-MEDINA, 2013).

Later, the number of galls, reproduction factors and number of protuberances were assessed by ANOVA and the averages of each treatment grouped together by the Scott-Knott test at 5\% error probability, through the software SASM- Agri (CANTERI et al., 2001). In addition, the values of variables, number of protrusions and reproduction factor were correlated by Pearson correlation analysis, using the statistical software SAS ${ }^{\circledR}$ (SAS 9.3, SAS Institute, Cary, North Carolina, USA). The resistances of potato genotypes were classified according to the FR values, considering as tough those whose nematode presented FR $<1.00$ and susceptible, those with FR $>1.00$.

\section{RESULTS AND DISCUSSION}

According to the results obtained in this study, all potato genotypes were susceptible (FR> $1.00)$ to $M$. javanica in comparison to the control, BRS Ana (Table 1). This confirms the pathogenicity of this species to potato crop (SILVA, 2009; LIMAMEDINA, 2013). 
Table 1. Average number of galls on the roots, number of protuberances in the tubers, reproduction factor and resistance of potato genotypes to Meloidogyne javanica.

\begin{tabular}{|c|c|c|c|c|c|c|}
\hline \multirow{2}{*}{$\begin{array}{l}\text { Genotypes } \\
\text { F23-11-06 }\end{array}$} & \multicolumn{2}{|c|}{ Number of galls } & \multicolumn{2}{|c|}{ Reproduction factor } & \multicolumn{2}{|c|}{$\begin{array}{c}\text { Number of } \\
\text { protuberances }\end{array}$} \\
\hline & 414.8 & $\mathrm{a}$ & 28.8 & $\mathrm{a}$ & $* *$ & \\
\hline F22-01-08 & 395.2 & $\mathrm{a}$ & 17.8 & $\mathrm{~b}$ & $* *$ & \\
\hline F189-09-06 & 369.7 & $\mathrm{a}$ & 30.0 & $\mathrm{a}$ & $* *$ & \\
\hline F23-24-06 & 247.3 & $\mathrm{~b}$ & 41.3 & $\mathrm{a}$ & 15.5 & b \\
\hline F38-03-07 & 245.8 & $\mathrm{~b}$ & 31.4 & $\mathrm{a}$ & 22.3 & $\mathrm{a}$ \\
\hline CL02-05 & 228.3 & $\mathrm{~b}$ & 11.3 & b & 7.5 & d \\
\hline F32-02-06 & 203.8 & $\mathrm{~b}$ & 36.2 & $\mathrm{a}$ & 19.8 & $\mathrm{a}$ \\
\hline BRS Ana (susceptible) & 192.2 & $\mathrm{~b}$ & 20.3 & $\mathrm{~b}$ & 7.9 & d \\
\hline BRSIPR Bel & 156.5 & $\mathrm{~b}$ & 23.8 & $\mathrm{~b}$ & 12.9 & $\mathrm{c}$ \\
\hline BRS F63 (Camila) & 131.8 & $\mathrm{~b}$ & 13.3 & $\mathrm{~b}$ & 7.2 & $\mathrm{~d}$ \\
\hline CV $(\%)$ & 49.4 & & 37.25 & & 37.25 & \\
\hline
\end{tabular}

* Means followed by the same letter in the column belong to the same group by Scott-Knott test at $5 \%$ probability of error; ** Genotypes with no produced tubers.

Considering the variable number of galls, the genotypes BRS F63 (Camila), BRSIPR Bel, F32-02-06, CL02-05, F38-03-07 and F23-24-06 showed a lower average damage caused by nematodes in the roots (popcorns, shown in Figure 1) but did not differ from the control BRS Ana, forming a group of genotypes significantly less damaged by nematodes, a group consisting of clones F23-11-06, and F22 F189-09-06 -01-08 (Table 1).

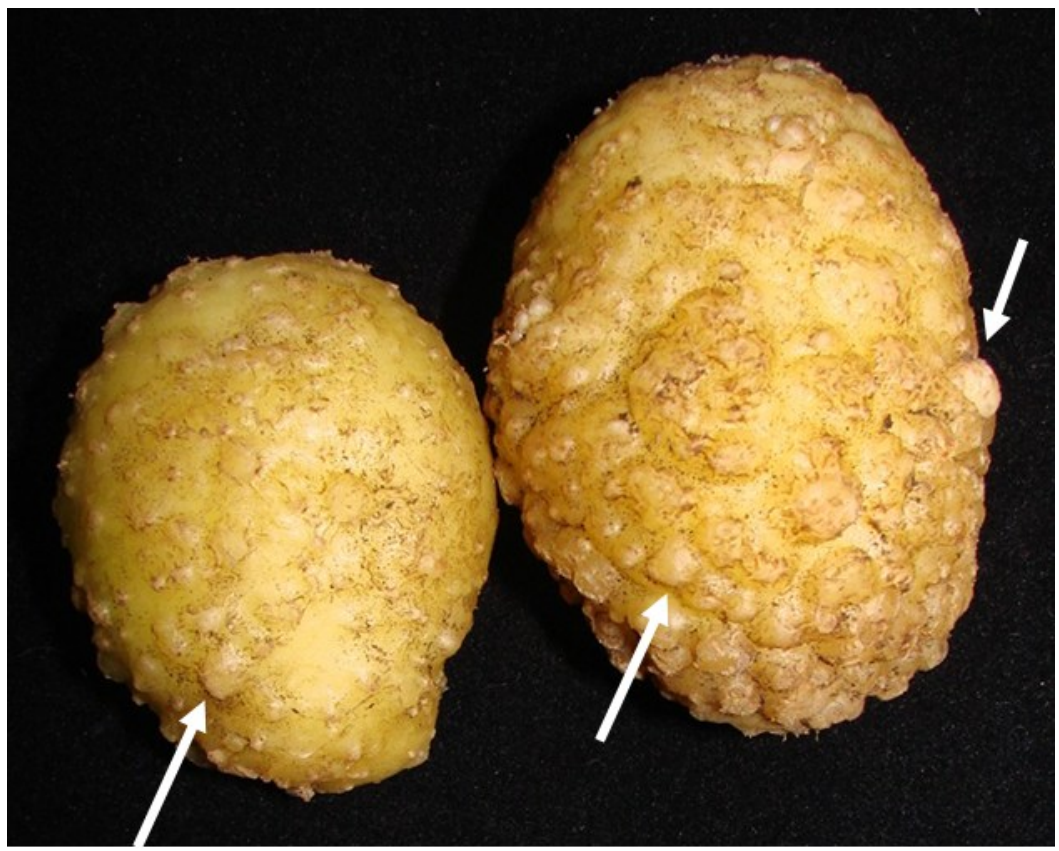

Figure 1. Tubers of potato cv. Bel BRSIPR from plants inoculated with M. javanica presenting protuberances ("popcorn") on the pell surface.

As for the reproduction factor (FR), the CL02-05 genotypes BRS F63 (Camilla), F22-01-08 BRSIPR Bel besides the control BRS Ana, presented significantly lower FR averages comparing to the group formed by clones F23-11-06, F189-09-06, F38-03-07, F32-02-06 and F23-24-06.

The high $M$. javanica FR values observed in the genotypes demonstrate the susceptibility of potato to this species of root-knot nematode. Charchar and Moita (1997), in the field work conducted in Brasília-DF with 48 potato genotypes, observed that only Achat cultivar showed resistance (moderate) to $M$. javanica. Silva et al. (2010) evaluated the resistance of seven potato genotypes to that species, under greenhouse conditions, and found good reproduction of the nematodes, with FR values ranging between 1.3 and 50.1. Pinheiro et al. (2013) evaluated the resistance of 14 advanced clones in a potato field naturally infested by the root-knot nematode verified that six genotypes showed resistance to infection by nematode. However these authors did not identified the species presenting in the area. However Lima-Medina (2013) verified the existence of cultivars resistant and moderately resistant to $M$. javanica by testing the reaction of 24 genotypes of wild potato (Solanum spp.) from the 
Potato Active Germplasm Bank of Embrapa.

In this work, the fact that the tested genotypes were found to be susceptible to nematode galls, can be attributed in part, to the influence of the high temperature $\left(25^{\circ} \pm 5^{\circ} \mathrm{C}\right)$ at which the test was performed. This temperature is optimal for the development of $M$. javanica (VAN GUNDY et al., 1985), but probably influenced the tuberization of clones F23-11-06 and F22-01-08. In potatoes, the optimum temperature for tuber initiation is approximately $17^{\circ} \mathrm{C}$, and temperatures above $30^{\circ} \mathrm{C}$ inhibit this process (ARALDI et al., 2011). The inhibition of tuber initiation of F23-11-06 and F2201-08 clones can also be associated with the high rate of multiplication of nematodes in infected roots. Such factors appear to be strongly associated with non-tuber initiation, since these same genotypes when inoculated a second time, had similar FR values and did not form tubers (data not shown).

The correlation between damage (number of protuberances) in the tubers and reproduction $M$. javanica (FR) for the group of evaluated genotypes was significantly positive $(\mathrm{r}=0.53 ; \mathrm{p}<0.01)$. This result corroborates with the reports of a similar study carried out by Lima-Medina (2013), when evaluated the resistance of different potato cultivars to different populations of $M$. javanica and observed positive correlation between these parameters $(0.81$ to $0.89 ; \mathrm{p}$ $<0.01)$.

Considering most potato cultivars in Brazil are susceptible to $M$. javanica and temperature is a critical factor for assessing resistance, more studies are required to determine the temperature condition that is at the same time favorable to the development of nematode and tuber of the potato plant, thereby enabling the detection of different levels of susceptibility / resistance in the potato germoplasm.

\section{CONCLUSIONS}

All evaluated potato genotypes are susceptible to $M$. javanica under greenhouse conditions $\left(25 \pm 5^{\circ} \mathrm{C}\right.$. $)$

\section{REFERENCES}

ARALDI, R. et al. Controle da tuberização: fatores do meio e os hormônios vegetais. Revista Científica Eletrônica de Agronomia, Garça, v. 10, n. 20, p. $1-9,2011$.

BONETI, J. I. S.; FERRAZ, S. Modificações do método de Hussey \& Barker para extração de ovos de Meloidogyne exigua em raízes de cafeeiro. Fitopatologia Brasileira, Brasília, v. 6, n. 3 p. 553, 1981.

BROWN, C. R. et al. Development and evaluation of potato breeding lines with introgressed resistance to columbia root-knot nematode (Meloidogyne chitwoodi). American Journal of Potato Research, New York, v. 83, n. 1, p. 1-8, 2006.

CANTERI, M. G. et al. SASM-Agri: sistema para análise e separação de médias em experimentos agrícolas pelos métodos Scott-Knott, Tukey e Duncan. Revista Brasileira de Agrocomputação, Ponta Grossa, v. 1, n. 2, p. 18-24, 2001.

CHARCHAR, J. M.; MOITA, A. M. Reação de cultivares de batata a uma infestação mista de Meloidogyne incognita raça 1 e $M$. javanica. Nematologia Brasileira, Piracicaba, v. 21, n. 1, p. 39-47, 1997.

CHARCHAR, J. M. Nematoides associados à cultura da batata (Solanum tuberosum L.) nas principais regiões de produção do Brasil. Nematologia Brasileira, Piracicaba, v. 21, n. 2, p. 49-60, 1997.

ESTEVES, I.; MALEITA, C.; ABRATES, I. Root-lesion and root-knot nematodes parasitizing potato. European Journal of Plant Pathology, Dordrecht, v. 141, n. 2, p. 397-406, 2015.

GOMES, C. B.; SOUZA, R. M. Doenças Causadas por Nematoides, In: PEREIRA, A. S.; DANIELS, J. (Eds.) $O$ cultivo da batata na região Sul do Brasil. Pelotas: Embrapa Clima Temperado, 2003. p. 321-349.

GRECO, N. Nematode problems affecting potato production in subtropical climates. Nematropica, DeLeon Springs, v. 23, n. 2, p. 213-220, 1993.

HUSSEY, R. S.; BARKER, K. R. A comparison of methods of collecting inocula of Meloidogyne spp., including a new technique. Plant Disease, Washington, v. 57, n. 12, p. 1025-1028, 1973.

LIMA-MEDINA, I. Diversidade de populações de Meloidogyne spp. e Pratylenchus spp. de diferentes regiões do Sul do Brasil produtoras de batata e estudo da patogenicidade em Solanum spp. 2013. 117 f. Tese (Doutorado em Fitossanidade: Área de Concentração em Fitopatologia) Universidade Federal de Pelotas, Pelotas, 2013.

OOSTENBRINK, M. Major characteristics of the relation between nematodes and plants. Mededelingen Landbouwhogeschool, Wageningen, v. 66, n. 4 , p. 1-46. 1966.

PINHEIRO, J. B. et al. Reação de clones avançados de batata em campo naturalmente infestado pelo nematoide-das-galhas. 1. ed. Brasília: Embrapa Hortaliças, 2013. 18 p. (Boletim de Pesquisa e Desenvolvimento 99). 
PINHEIRO, J. B.; SILVA, G. O.; PEREIRA, R. B. Nematoides na Cultura da Batata. 1. ed. Brasília: Embrapa Hortaliças, 2015. 12 p. (Circular Técnica 143).

SILVA, A. R. et al. Reação de clones e cultivares de batata avaliados em casa de vegetação a Meloidogyne incognita, $M$. javanica e $M$. mayaguensis e in vitro a $M$. javanica. Nematologia Brasileira, Piracicaba, v. 34, n. 1, p. 48-55, 2010.

SILVA, A. R. Fitonematoides na cultura da batata: Reação de genótipos a Meloidogyne spp., distribuição de espécies e caracterização dos sintomas. 2009. 115 f. Tese (Doutorado em Agronomia: Área de Concentração em Produção Vegetal) - Universidade Estadual Paulista, Jaboticabal, 2009.

VAN GUNDY, S. D. Ecology of Meloidogyne spp. emphases on environmental factors affecting survival and pathogenicity. In: SASSER, J. N.; CARTER, C. C. (Eds.). An advanced treatise on Meloidogyne. North Carolina: Raleigh. 1985, v. 1, cap. 15, p. 177-182.

VOVLAS, N. et al. Pathogenicity of the root-knot nematode Meloidogyne javanica on potato. Plant Pathology, London, v. 54, n. 5, p. 657-664, 2005.

YOUSSEF, M. M. A. Potato nematodes and their control measures: a review. Archives of Phytopathology and Plant Protection, London, v. 46, n. 11, p. 1371-1375, 2013.

ZAMBOLIM, L. Produção integrada da batata. Volume I. 1. ed. Viçosa, MG: Universo Agrícola, 2011.438 p. 